\title{
Reading Comprehension Profile of Czech Garden Variety Poor Readers
}

Pavla Presslerova

\section{doi: 10.18355/PG.2016.5.2.424-442}

\begin{abstract}
The aim of this study is to analyze the reading comprehension skills of garden variety poor readers (further referred to as GVPR) in the $4^{\text {th }}$ grade. This group of students is rather incoherent and compared to special educational needs pupils GVPR are rarely targeted with intervention or diagnosis. From the total of 134 tested students, 16 students were found underachieving in all criterion-referenced tests and have therefore, in all of their results, been placed in the lowest quartile of all students. Furthermore, the GVPR's results pointed out underachievement in not only decoding, but also in reading comprehension. Finally, the study contains a more detailed description of the reading profile of a GVPR.
\end{abstract}

\section{Key words}

decoding, poor reader, reading comprehension, reading deficit, reading literacy

\section{Introduction}

In the Czech educational psychology tradition, the diagnosis and targeted intervention in reading are aimed mostly for special educational needs students, especially for dyslexic students (eg. Matějček, 1995; Jucovičová, Žáčková, 2008, Zelinková, 2009; Pokorná, 2010; Kucharská, 2014 , aj.). However, there are a lot of children, who have difficulties with reading and whose problems are not connected to dyslexia (Snowling, 2009). In terms of differential diagnosis, the difficulty with reading can be a result of mental or cognitive deficit of a student, visual, hearing or speech impairment (e.g. development dysphasia) (Bishop \& Norbury, 2002). Moreover, some students can find reading difficult because they suffer from one of the many forms of the ASD. (Ricketts, Jones, Happé, \& Charman, 2013). The study of Foorman et al. (1998) states that approximately, 17\% of children can be identified as struggling readers. This statement is in agreement with the statements of Conners \& Olson (1990), or Nation et al. (2004); Nation (2005). These all claim one fifth of all children's population to have difficulties with reading.

To sum up, the difficulties with reading are caused by a wideranging etiology. It is important to mention that if a student has difficulty with reading, it is certainly not an isolated problem. The reading ability influences every aspect of students' educational process. The current pedagogical discourse does not perceive reading as an isolated skill; however, it is viewed as a complex process based on language, cognition and motivation (Kucharská et al., 2014). The interest is then drawn

Slavonic Pedagogical Studies Journal, ISSN 1339-866o, Volume 5 Issue 2, September 2016 
particularly to literacy. Literacy is not understood as simple skill of reading and writing, which is learned in students' first years in primary education. We agree with Wildova's (2005) statement, that it is not crucial to read a piece of text, but it is crucial to read a text and understand its message, to critically judge the message and to know how to use the needed information. These abilities help the student develop a positive attitude towards reading. Literacy is considered a key competence. The lack of literacy skills has major consequences further in students' life. The role of literacy in educational process is also crucial because there are further theoretical, as well as purely practical, findings inaccessible without the key literacy skills.

One of the many key literacy skills is decoding, i.e. to be able to connect speech parts to their graphical form. However, this skill cannot stand on its own. The main goal of literacy is to understand the message of words, phrases as well as coherent texts and to be able to further work with the message (to directly draw conclusions, to interpret and integrate isolated information, to critically reflect on the message, to take a stand on the message etc.). Unfortunately, the reading comprehension aspect is often disregarded in the diagnosis of reading difficulties, or there is a minimal attention paid to it in comparison to the technical aspects of reading (speed, correctness, mistakes ratio). In the presented study, we are trying to study the reading comprehension in more depth.

This article is based on the project Reading Comprehension Typical Development and Its Risks. ${ }^{1}$ This project consists of two parts. First part focuses on the definition, description and interpretation of individual and development connections, and on the development of the reading comprehension of students in the first four years of their primary education $\left(1^{\text {st }}-4^{\text {th }}\right.$ grade). The study wants to describe the development of reading comprehension in a group of students from the beginning of their first encounter with reading till $4^{\text {th }}$ grade. It is supposed that the quality of the reading technique of a $4^{\text {th }}$ grade student is considered relatively high. The first part also aims to observe different reading teaching methods (the analytic-synthetic method and the genetic method) and to monitor the differences between them. The second part of the project concentrates on high-risk factors of reading comprehension of the high-risk group of students in $4^{\text {th }}$ grade. Concretely, four groups were selected - Specific learning difficulties (SLD) students, specific language impairment (SLI) students, (autistic spectrum disorders (ASD) students - with Asperger syndrome and the above mentioned GVPR.

As stated above, the study is interested in both crucial aspects of literacy - decoding and reading comprehension. The Simple View of Reading Model (Gough \& Tunmer, 1986) is used in the study to facilitate the process of identification of the individual types of readers. This model

\footnotetext{
${ }^{1}$ The article was financially supported by Czech Science Foundation. It is a constituent part of outputs of grant project for the Faculty of Education Charles University in Prague - "Reading comprehension - typical development and its risks" P407/13-20678S.
} 
identifies four different profiles of young readers. The model is based on the theory that in order to successfully master reading, it is necessary to master both main factors - decoding and linguistic comprehension. Graphically, this model can be represented by four quadrants that are split in the middle by two perpendiculars. One line represents decoding, the other represents linguistic comprehension. Each of the lines has two poles positive and negative. This divides the area into four quadrants and each quadrant represents one type of reader. Most children belong to the group of "Good Readers". Their results are positive in both crucial disciplines. Next group, "Poor Comprehenders" have positive results in decoding, however, their linguistic comprehension results are negative. It is generally problematic to uncover this kind of difficulty. The reader is able to read fluently without any mistakes, and if the teacher does not put emphasis on the comprehension skill, he or she might not notice that the literacy of the reader might be at risk.

The third group are readers whose decoding skills are lower than the norm but it does not affect their linguistic comprehension ability. Generally, this is the group where dyslexic students belong (Snowling, 2009). Children, whose decoding and linguistic comprehension skills are below the norm, belong to the fourth quadrant. Firstly, they do not manage to decode the text. This means that their phonemic inventory is insufficient, or they struggle with recognizing individual graphic symbols (e.g. Kessler $\&$ Caravolas, 2011). The fourth group is the object of our study. The children in this group read slowly, with mistakes and not fluently. In addition, they are rarely capable of summarizing the meaning and the nature of the text.

This group is in our opinion at the highest risk of complete functional illiteracy. The Simple View of Reading Model identifies this group as a group with unspecified broad based language deficit. Other professionals refer to this group as "garden variety poor readers" (Stanovich, 1988; Catts, Hogan, \& Fey, 2003; Share, 2006). The group can be recognized by the broad variability in etiology of the various reading difficulties. The difficulties are admittedly caused by multiple factors and a broad spectrum of reading difficulties is related to this group. In case of specific learning disorders, the causes for the impairment can be found in the neurobiological background of the reader, however, in case of GVPR, the cause will in many cases never be revealed. Very often, the difficulty is caused by a combination of multiple backgrounds - socio-economical, motivational, phonological, cognitive, organic, or didactic. In case of dyslexia, it is possible to show the problems in phonological part of language, in proportionate reading stimulation, intellectual ability and educational supervision. It is almost impossible to find such an easy etiologic trajectory for GVPR. The only exception is when the difficulty is caused by low intelligence quotient. To sum up, GVPR can be described as an incoherent group of students, with a large variability of partial dysfunctions causing the reading difficulties. 
Based on the observation of the selected group of Czech $4^{\text {th }}$ grader readers, the following research questions on garden variety poor readers were designed.

1 , What is the share of GVPR in the sample group?

2, Does the GVPR group perform poorly in all tested areas?

3 , Does the number of GVPR vary according to the reading teaching method?

4, Does the lexicon of GVPR differ compared to the lexicon of children with typical development?

\section{Methodology}

\section{Selected of participants}

The subject of this study was a group of 4th grade students from different primary school. This age group was picked intentionally, as in the $4^{\text {th }}$ grade, students have already acquired all the skills needed for a good reading technique (good speed of reading, low number of mistakes, adequate reading technique). All the previously mentioned qualities eliminate the problems caused by the ongoing process of reading skills acquisition; in particular the choice eliminates the problems caused by personal differences (shifted starting point, etc.), teaching methods, different pace of individual teacher, etc. When students reach $4^{\text {th }}$ grade, reading difficulties become significant. In addition, reading comprehension in $4^{\text {th }}$ grade, has already achieved a good quantifiable level.

Altogether, the study involved 517 students from $1^{\text {st }}$ to $4^{\text {th }}$ grade. This article is analyzing the data of the group of 134 students of 4th grade. Seventeen primary schools from Prague, Central Bohemia and South Bohemia took part in the study. The primary school represented a wide demographic spectrum and included language grammar schools in the metropolis, schools from residential areas, schools in small villages, ecclesiastic schools, as well as schools with mixed-age grouped classes. It was also important that the reading teaching methods were represented equally. In the Czech Republic, there are two prevailing reading teaching methods analytic-synthetic method and genetic method. The first method has a longer tradition in Czech schools and dominates in Czech educational system. This methodological and didactic plurality allows a more detailed research and understanding of children's writing acquisition.

Analytic-synthetic method is based on speech particles, concretely on phones and syllables. Hearing ability is important for this method. Children first learn to break words into separate phones, then syllables, and the third step is to put the syllables back together to create a word. The genetic method is based on spelling all phones separately and creating a word. This method is closely tied with writing. Children first learn to write capital letters and lower-case letters come later. The genetic method also presents children with longer written accounts earlier than the analytic-synthetic method. One of the goals of this study is to find out, what are the differences between the reading skills of the students, who learn to read through the two different methods. 
For more information on basic characteristic of the group see the following table.

Table 1. 4th graders divided by reading method and gender

\begin{tabular}{llll}
\hline Gender & AS method & G method & Sum \\
\hline Boys & 31 & 40 & 71 \\
Girls & 32 & 31 & 63 \\
\hline Sum & 63 & 71 & 134 \\
\hline
\end{tabular}

The average age of the respondents was 117 months (nine years and nine months), $\mathrm{SD}=5,13$, min. 100 months, max. 135 months. In order to be allowed to take part in the study, all children's parents/carers had to fill in, sign and return a parental consent.

The data was collected in two stages. On the whole, every student attended five hour-long sessions. Four of these sessions were individual and took part at school during their school time. Children had an allocated classroom and were supervised by a trained administrator. Last session was a group session. This article presents the data from the first stage of data collection (T1), i.e. the data collected after three individual sessions.

\section{The set of tests}

When designing the methodology and the final set of tests the research team was inspired by $\mathrm{Czech}$ and international researches of reading development diagnostics, however, the goal was also to enrich Czech diagnostic portfolio with new methods. The newly created tests are designed in a way that they put emphasis on the reading comprehension level, and at the same time include the evaluation diagnostic requirements of educational psychologists as well as of teachers. As a result, more than 30 diagnostic tools were used in the course of the five sessions. The exact number of tools differed according to students' age. Some tools were used twice in order to allow us to observe the development curve and to add on to the validity of the results. They were used once in the first stage and for the second time in the second stage. The time gap between the two stages was on average 6 months; the minimal gap between two sessions was two weeks.

Generally, the tools were designed to test following areas:

- Measurement of speed and correctness of reading (decoding)

- Description of reading comprehension

- Listening comprehension

- Description of phonological awareness

- Description of phonological skills

- Linguistic area, lexicon

Slavonic Pedagogical Studies Journal, ISSN 1339-866o, Volume 5 Issue 2, September 2016 
- Silent reading

- Writing skills

- Personal motivation area

- Environmental influences

\section{Methods used to identify garden variety poor readers}

As mentioned before, the identification of individual readers is based on the so-called Simple View of Reading Model (Gough \& Tunmer, 1986). In accordance with this theory, it was observed, whether the children's result will always fall into the lower achievements group. Two tests were chosen to observe similar skills. These two tests, however, differ in their main characteristics. One test was taken as a ready-made material from abroad and the other one was newly prepared for this study. In order to allow a better comparison, each set of two tests was accompanied by a third test. The third test's aim was to help create a detailed profile of the group of GVPR. Furthermore, the study analyzes other areas which were considered important for high-risk readers and compares them to the group with typical development. In order to compare these two groups we focused on the areas of language and cognition.

\section{Tools for Assessment of Decoding Skills}

- One Minute Reading Test (Caravolas \&Volín, 2005) consists of reading separate words from a list of 140 frequently occurring Czech words. The order of the words is strictly given and the children get a time limit, one minute. Within the time limit, they have to read, correctly and as quickly as possible, as many words as possible. Because they are reading separate words, they do not need to concentrate on the context of the text, which allows for a deep analysis of their reading technique.

- Rabbits (Kucharská \& Mrázková, in Kucharská et al., 2014) is a test newly created for this study. This test respects all the principals of methods used in Czech educational psychology practice (e.g. Matějček et al., 1987). The test consists of a coherent text. The children read the text out loud, which allows the assessment administrators to observe all the technical aspects of reading - the number of words read in one minute, the number of mistakes, the total time of reading, and other quantitative coefficients. Since this is a draft version of the test, used for the first time in this study, no normative data are available for this test.

- Reading of Pseudowords (Caravolas \&Volín, 2005) consists of reading a list of 24 pseudowords. These words do not exist in Czech language and do not carry any meaning; however, they respect all the phonological rules Czech language. The students are asked to read the words in order, as fast as possible, as correctly as possible. 


\section{Tools for Assessment of Reading Comprehension Skills}

- Rabbits (Kucharská \& Mrázková, in Kucharská et al., 2014) was used also to assess the reading comprehension. In Czech educational psychology practice, reading comprehension is assessed by two independent specialists. The student is asked to read a text and retell the story. This kind of assessment can be very subjective as the two specialists might not agree on how precisely the student covered the plotline of the story or how he or she understood the details of the story. It can also be a disadvantage for students based on their character treats - some of them might understand the text, but are not able to retell the story. Furthermore, some students might be afraid of answering incorrectly in the examination or might be shy to answer the questions, which then influences their ability to formulate their answers. Therefore, this newly developed test aims to provide a more precise assessment of the reading comprehension.

The test evaluates the general comprehension of the story as well as the student's ability to read in between the lines. The evaluation is made through the medium of questions, which the child answers after reading the text in its entire length. This is how this evaluation form differs from Reading Exams (Matějček et al., 1987). In the Reading Exams students are allowed to stop reading after three minutes and the administrators then ask questions about the finished part of the test. This can greatly influence the results as the student might be able to process a small part of the test, however, is not be able to process the message of the whole of the text.

- The Reading Comprehension Test (Caravolas \& Volín, 2005) consists of 20 meaningful sentences. In each sentence, there are two words left out. It is up to the students to chose, from a list of five distractors, the most convenient word for each gap. The time limit for the activity is seven minutes. This test measures the ability to understand the context of a sentence. There are two possible marking schemes of this test, one can either work with the whole of 40 points (1 point for one word filled in correctly) or with the whole of 20 points (1 point for one correct sentence). This test can be conducted in a group session.

- Little Star, listening comprehension task, is another newly designed test. It is aimed to evaluate the listening comprehension of respondents. Students listen to a story, which resembles a fairy tale, and afterwards are given questions. The questions evaluate students' understanding of the story, understanding of the context of the story, as well as details about the story. Since this is a draft version of the test, used for the first time in this study, no normative data are available for this test.

\section{Tools for Assessment of Language Skills}

- Test of Language Awareness (Kucharská \& Šmejkalová, in Kucharská et 
al., 2014) is another test created for this study. This test evaluates grammar and language sensibility of children. It consists of two parts: morphology and word formation. Both parts are further divided into 4 counterparts and each counterpart contains 5 tasks. These five tasks represent the same grammatical concept. Since this is a draft version of the test, used for the first time in this study, no normative data are available for this test.

- Vocabulary (Málková \& Smolik, in Kucharská et al., 2014) is a test created to assess the passive lexicon of an individual student. The test is presented in the form of 36 cards; each card shows four pictures. The student is then asked to pick one picture that represents the incentive word. Students obtain one point for each word marked correctly.

\section{Results}

Firstly, the criteria to identify a student as a GVPR were chosen. Because of the size of the set of tests, several key ones were picked. The concrete form and descriptions of all tests can be found above. These methods were then described as criterion-referenced. The next step was to determine what the threshold score for a low ability result is. A threshold score had to be set for each test separately. This score cannot be described as a norm-referenced assessment, as the value depended on the results of all the tested $4^{\text {th }}$ graders. Based on a profound study of relevant sources (e.g. Rutter\&Yule, 1975; Ellis\&Large, 1987; Stanovich, 1988, 2005; Torppa et al., 2006), it was decided that the $25 \%$ of students with the lowest scores will become the object of this study. In other words, the fourth of all students with the worst results were chosen for the study. Roughly, this would count 34 respondents, which is a greater number than the number of GVPR in the $4^{\text {th }}$ grade. This size of the sample will help to a more effective comparison; the comparison will then lead to a more precise identification of the repeatedly poor results of some students. It is important to mention, that this step was conducted separately for those who learned to read using analytic-synthetic method and for those who acquired the reading skills using the genetic method. This method was used to help determine whether the percentage of underachieving students differs in these two groups. The last step was to observe how stable or unstable the results of the two groups from the lower achievement quartile are.

It requires attention that GVPR have difficulty not only with decoding, but also with linguistic comprehension. In order to identify a student as a GVPR, he or she has to achieve low scores in both of these areas. The speed of reading was the first observed parameter. This parameter has a long tradition in Czech educational psychology practice and is crucial for identifying specific reading disabilities. The key value is the number of correctly read words within the first minute of reading. It has been repeatedly proven that this quantitative tool has a high potential of differentiating. It is also an efficient way to distinguish technically advanced readers from low ability readers.

Two tests were employed in the process of identification of a 
GVPR - One Minute Reading Test and the new Rabbits test. Both these tests measure the ability of a student to decode. First test consists of a list of isolated, frequently occurring Czech words, the level of difficulty progressively rises. The second test consists of reading a coherent text. Each of the tests requires a different reading strategy.

The table below provides an overview of the average results of all tested $4^{\text {th }}$ graders. The threshold values for each test and the comparison of the two teaching methods. The threshold values show, what scores the students had to achieve in order to belong to the category of potential GVPR. To provide a clear overview of all results, the table also includes a column showing the range of minimal and maximal achieved scores of all respondents $(\mathrm{N}=134)$.

Table 2. A rough analysis - decoding

\begin{tabular}{|c|c|c|c|c|c|c|}
\hline & $\begin{array}{c}\text { Aver } \\
\text { age }\end{array}$ & SD & $\begin{array}{l}\text { Range } \\
\text { (min.- } \\
\text { max.) }\end{array}$ & $\begin{array}{l}\text { Thres } \\
\text { hold } \\
\text { Value } \\
\text { (AS) }\end{array}$ & $\begin{array}{l}\text { Thre } \\
\text { shold } \\
\text { Valu } \\
\text { e (G) }\end{array}$ & $\begin{array}{c}\text { Number of } \\
\text { students in } \\
\text { lower } \\
\text { quartile } \\
\text { (AS/G) }\end{array}$ \\
\hline \multicolumn{7}{|l|}{ Reading tests } \\
\hline $\begin{array}{l}\text { One Minute } \\
\text { Reading Test }\end{array}$ & 90,8 & $\begin{array}{c}16 \\
7 \\
\end{array}$ & $53-127$ & 79 & 76 & $17 / 18$ \\
\hline \multicolumn{7}{|l|}{ Rabbits } \\
\hline $\begin{array}{l}\text { Number of } \\
\text { words in } 1 \text { st } \\
\text { minute }\end{array}$ & 94,5 & $\begin{array}{c}26, \\
1\end{array}$ & $46-156$ & 75 & 75 & $16 / 18$ \\
\hline
\end{tabular}

The difference between the best and the worst score is very large in the tests that observe the speed of reading (decoding parameter). The difference is three times bigger in the test that contains reading of a coherent text. Both of the tests are, however, very similarly effective in their results - both marked almost the exact same number of students with poor decoding skills. The One Minute Reading Test marked 35 respondents whilst the Rabbits test pointed out a group of 34 students. The criterion value, the minimal number of correctly read words in order to not fall into the GVPR group, is similar for both tests. The only difference, which is considered on the border line of statistic importance, is the results of the students who acquired reading skills through the analytic-synthetic method. Their ability to read isolated words is according to the results on a higher level. In a broader perspective, when comparing the results of students of all grades, it was found that some $1^{\text {st }}$ graders achieved higher scores than a $4^{\text {th }}$ grade GVPR. The best reader in the $1^{\text {st }}$ grade achieved the result of 80 correctly read words. Furthermore, the data show that identified students with poor

Slavonic Pedagogical Studies Journal, ISSN 1339-8660, Volume 5 Issue 2, September 2016 
decoding skills on average achieve results of one year old younger students. In the first term, the students in the $3^{\text {rd }}$ grade were generally able to read 78 words correctly.

The Rabbits show very similar results. An average score of a student, in the first term of the $3^{\text {rd }}$ grade, is 80 words read correctly. The threshold score of the $4^{\text {th }}$ grade students was established at 75 correctly read words. The conclusion can be drawn that an average $4^{\text {th }}$ grade GVPR's reading ability is slightly worse than the ability of an average $3^{\text {rd }}$ grade student. Their decoding skills development is at least one year behind.

To compare the two testing tools, it can be summed up that the new contextual test (Rabbits) measures very similar values as the standardized test (One Minute Reading Test). Similarly, the identified group of readers with insufficient decoding skills resembles in both cases.

The data collection and the analysis of the reading comprehension skills of the students were also conducted using two different tests. The two tests are based on different concepts. The Reading Comprehension Test is focusing on the meaning of short pieces of text. The students receive a short text - two to three sentences long - with gaps. In every piece of text, the students are asked to fill in two gaps. They pick the missing words out of a choice of 5 words, 4 of them are distractors. The distractors chosen as follows: first distractor has a semantic link to the text, the second distractor resembles phonologically, the third distractor has a similar graphical form, and the fourth distractor has no direct link to the text. There is also a time limit given for this test.

The newly created test, Rabbits, was chosen as the second research tool for the analysis of the reading comprehension skills. This test evaluates the reading comprehension using a longer narrative written account. The narrative is realistic and students can easily relate to the story. The text is followed by a large portfolio of questions. The students read the text out loud and then, the administrator asks them questions regarding the plotline details, the timeline, the characters, and in text mentioned objects (explicit score). The second observed aspect is implication. The administrator observes to what extend the student understands broader context of the text, the meaning of words and the meaning of various word expressions. For example, the students are asked to explain expressions which do not convey their meaning straightforwardly, e.g. "break a leg". 
Table 3. A rough analysis- linguistic comprehension

$\begin{array}{cccccc}\begin{array}{c}\text { Aver } \\ \text { age }\end{array} & \text { SD } & \begin{array}{c}\text { Range } \\ \text { (min.- } \\ \text { max.) }\end{array} & \begin{array}{c}\text { Thres } \\ \text { hold } \\ \text { value } \\ \text { (AS) }\end{array} & \begin{array}{c}\text { Thre } \\ \text { shold } \\ \text { value } \\ \text { (G) }\end{array} & \begin{array}{c}\text { Number of } \\ \text { students in } \\ \text { lower } \\ \text { quartile } \\ \text { (AS/G) }\end{array}\end{array}$

\begin{tabular}{lcccccc}
\hline Reading tests & & & & & & \\
\hline $\begin{array}{l}\text { Reading } \\
\text { comprehension } \\
\text { test }\end{array}$ & $\begin{array}{c}22,9 \\
4\end{array}$ & $\begin{array}{c}6,5 \\
4\end{array}$ & $9-39$ & 18 & 18 & $17 / 18$ \\
\hline $\begin{array}{l}\text { Rabbits } \\
\text { (reading }\end{array}$ & $\begin{array}{c}12,5 \\
\text { comprehension) }\end{array}$ & $\begin{array}{c}2,5 \\
7\end{array}$ & $0-20$ & 10 & 10 & $23 / 29$ \\
\hline
\end{tabular}

Similarly to the decoding result, a large range of scores can be observed in the reading comprehension tests. In Rabbits, the lowest achieving student could not answer any questions correctly, whereas the highest achieving student answered all questions correctly. The new test proved to be more difficult for the respondents. In comparison to the expected $25 \%$ of lower quartile students, the results of $38,8 \%$ of all students were put in the lower quartile (52 respondents). The Reading Comprehension Test identified a group of only 35 lowest achieving students. This difference was caused by the fact that a large number of students achieved a score equal to the threshold score. In conclusion, in the first term of the $4^{\text {th }}$ grade, the average score in the Reading Comprehension Test (implicit + explicit partial score) was approximately 23 points. The threshold score was established at 18 points. This value is equal to the average score value of a student in the $3^{\text {rd }}$ grade in the same period of time.

Based on the analysis of the results of all 4 applied tests, we identified a group of 10 respondents, whose results were in the lower quartile in all observed areas. To achieve low scores in all four tests was the condition for identifying a student as a GVPR. Five of the identified respondents were taught through the analytic-synthetic teaching method and five respondents were taught through genetic method. In percentage, there were 8\% GVPR in analytic-synthetic method and $7 \%$ in genetic method. In the whole group $(\mathrm{N}=134)$, there are $7,4 \%$ of GVPR.

Because the above mentioned model identifies a very small number of GVPR, the study decided to apply a less strict model of identification of a GVPR. As a result, a group of students, whose results in one of the decoding tests and one of the reading comprehension tests were in the lower quartile, was identified. It was important to decide which test from each category was going to be the deciding factor. For decoding skills, the

Slavonic Pedagogical Studies Journal, ISSN 1339-866o, Volume 5 Issue 2, September 2016 
One Minute Reading Test was found more convenient, as the readers were reaching higher scores in this test. This was supposedly caused by the fact that reading isolated words is easier since students are not distracted by the context of the written account. The inability to understand the context of the text may slow some the reading of some students down. Therefore, it is believed that the One Minute Reading Test reflects better on pure ability of decoding. The Rabbits test was then found more convenient as a deciding factor for the reading comprehension aspect, as it shows a complex picture of the ability of a reader to understand a longer written account, not just sentences.

As GVPR were identified those students whose achievements were in the lower quartile in the One Minute Reading Test as well as in the Rabbits test (its' reading comprehension part). The following table presents the division of all respondents according to the Simple View of Reading Model (Gough \& Tunmer, 1986).

Table 4. Division of readers according to the Simple View of Reading Model divided by teaching methods

\begin{tabular}{lcccc}
\hline & \multicolumn{2}{c}{ AS } & \multicolumn{2}{c}{ GE } \\
\cline { 2 - 5 } & $\mathrm{N}$ & $\%$ & $\mathrm{~N}$ & $\%$ \\
\hline Good Readers & 31 & 49 & 32 & 45 \\
\hline Dyslectics & 9 & 14 & 10 & 14 \\
\hline Hyperlexic students & 15 & 24 & 21 & 30 \\
\hline Garden Variety Poor Readers & $\mathbf{8}$ & 13 & $\mathbf{8}$ & 11 \\
\hline
\end{tabular}

In analytic-synthetic method, this new identification model pointed out 8 students, whose results were in the lowest quartile in both tests. 8 students stand for $13 \%$ of all respondents from the analytic-synthetic teaching method group. The same number of students was identified in the genetic teaching method group ( 8 of the 74 total number), which is $11 \%$ of all readers from this group. In total, the new identification model pointed out $12 \%$ of GVPR. This is because the identification criteria are less strict than in the first case. It is necessary to mention, that this percentage is only connected to the results of the two above mention tests and it must not be understood as a final result for the whole set of tests. The relatively high percentage of students with a deficit in the reading comprehension is believed to be caused by two factors. Firstly, Rabbits is a higher difficulty level test; secondly, a high number of students obtained the threshold score in one of the tests. Obtaining the threshold score meant that their results were included in the high-risk group. It is, however, not expected, that the percentage of students with a reading comprehension deficit is this high as the article presents a partial analysis of the results. Similar studies have shown that the percentage of readers with good decoding skills and a reading comprehension deficit reaches usually, at maximum, 10\% (e.g. 
Nation, 2011; Schöffelová \& Mikulajová, 2012).

Since the second identification model pointed out a larger percentage of GVPR, the results were also used as the base for our following analysis. As it was already mentioned in the methodological part of this article, apart from observing criterion-referenced tests, the study also focuses on observation of the results of the GVPR group in all other disciplines. This allows the study to show more varied reading profile of this high-risk group.

\section{Comparison using other tools}

To further analyze the decoding skills of the readers, the Reading of Pseudowords (Caravolas \& Volín, 2005) was taken into consideration. The readers find this test difficult as the task is to read as quickly as possible a list of neologisms, words that do not exist in Czech language. However, all the neologisms must respect the Czech phonological rules. The results are based on the number of words read in the time limit of one minute.

Table 5. Comparison of the results in Reading of Pseudowords - Typical Development Group and Garden Variety Poor Readers

$$
\text { Average SD } \begin{gathered}
\text { Range } \\
(\min .-m a x .)
\end{gathered}
$$

\begin{tabular}{lccc}
\hline $\begin{array}{l}\text { Reading of } \\
\text { Pseudowords }\end{array}$ & & & \\
\hline Typical Development grou & 19,9 & 4,36 & $0-28$ \\
& & & \\
Poor readers group & 9,5 & 5,4 & $0-19$ \\
& & 5 & \\
\hline
\end{tabular}

The scores of all the $4^{\text {th }}$ grade students show, that this test is very difficult. It is comprehensible that the pace of reading pseudowords is remarkably slower than the pace of reading a normal text. On average, GVPR read correctly 9,5 words. The number of words read incorrectly was high - 9,3 words on average. The range was wide (1-23 mistakes) and the $\mathrm{SD}=6,22$. This tests points out the insufficient decoding skills of GVPR. In addition, this test confirmed that there is a significant difference $(p=0,05)$ between GVPR and readers with typical development. Diagnostically, this test brings very high quality results on decoding skills of the readers.

Another way to examine the reading comprehension skills of the readers is to examine their listening comprehension skills. The Little Star test was

Slavonic Pedagogical Studies Journal, ISSN 1339-866o, Volume 5 Issue 2, September 2016 
developed for this study. This test contains an audio version of a story about a restless star. The story was chosen purposefully so that the respondents can relate to it. The length of the test is 167 words and it is read by a professional, with artistic focus on direct speech. After listening to the test, the administrators asked questions from a prepared question sheet. Listening comprehension has till nowadays been overlooked in Czech educational psychology practice. However, the skill of listening and understanding has a major impact on the literacy of students.

Table 6 - Comparison of the results in The Little Star - Typical Development Group and GVPR group

$$
\text { Average SD } \begin{gathered}
\text { Range } \\
\text { (min.-max.) }
\end{gathered}
$$

\begin{tabular}{lccc}
\hline The Little Star & & & \\
\hline Typical Development grou & 11,8 & 3,2 & $4-19$ \\
Poor readers group & 9,2 & 4,1 & $4-16$ \\
\hline
\end{tabular}

Even though listening comprehension, at first sight, does not seem to have direct connection to reading, the GVPR group had significantly lower results even in this area of study. This finding is crucial because spoken word plays a major part in education - verbal announcements, descriptions, explanations, etc. The results show how high is the risk of a complete failure in education of GVPR. The results of GVPR group in the first term of the $4^{\text {th }}$ grade were comparable to the average results of $2^{\text {nd }}$ grade students.

Based on the primary identification of the GVPR group, the next part of our analysis focuses on another possible precursor of reading comprehension difficulties - language awareness. Two newly designed tests were employed in order to analyze the language awareness of the respondents. First of them, Test of Language Awareness (Kucharská \& Šmejkalová, in Kucharská et al., 2014), observes students' knowledge of morphology and syntax. The second test, Vocabulary (Seidlová-Málková \& Smolík, in Kucharská et al., 2014), studies the extent of the receptive lexicon of students. This test resembles in its form to a commonly used test of British origin - British Picture Vocabulary Scale. Many research projects in the past concluded that GVPR have a low level of language perception in their native language ( Leach et al., 2003; Snowling \& Hulme, 2011) In their conclusions, the low level of language perception is, together with low decoding skills ability, one of the main causes for insufficient reading comprehension skills. This part of the study focused on finding whether the 16 previously identified students in the GVPR group achieve low results also in the language awareness tests. 
Table 7. Comparison of language tests - Typical Development group and GVPR group

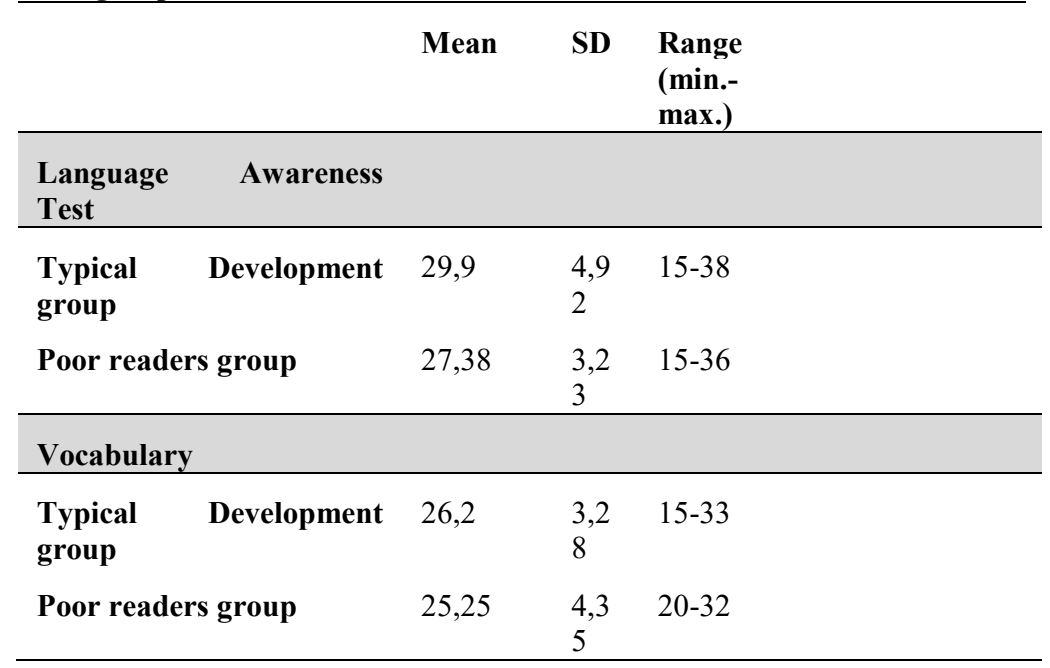

The collected data surprisingly do not support the hypothesis. The GVPR group did not achieve remarkably lower results in any of the two tests $(\mathrm{p}=0,05)$. This information suggests that in preparing intervention and support of reading comprehension for GVPR group, it is possible to use passive lexicon of students, as well as morphological and syntactical sensibility. Also, the results can be useful in comparing GVPR to other high-risk groups, e.g. children suffering from developmental dysphasia and dyslexic children often show low level of language sensibility. Therefore, this part of the set of tests could serve as differentiating parameter of the diagnostic process.

\section{Discussion and Conclusion}

The study proves that the concept of garden variety poor readers is for authors researching reading comprehension very problematic. There are varied approaches to identify a GVPR. The study can also relate to the concept of unspecified reading disability. The collected data show, that the etiology of reading difficulties can be extremely variable. The study divides readers into four groups according to the Simple View of Reading Model (Gough \& Tunmer, 1986). Based on all the achieved scores, a group of 16 GVPR was selected ( 8 from analytic-synthetic teaching method group, 8 from genetic teaching method group, gender division: 9 boys, 7 girls). The model of identification of a GVPR proved to be appropriate. It was also proven that GVPR achieve low scores in decoding, reading comprehension, and listening comprehension. On the other hand, it was surprising that the group does not show underachievement in language awareness skills (morphological and syntactical). In addition, the passive lexicon of the students is in norm with the rest of the tested group of all $4^{\text {th }}$ grade students.

Slavonic Pedagogical Studies Journal, ISSN 1339-866o, Volume 5 Issue 2, September 2016 
These facts could in the future help with improvement of differential diagnostics of reading difficulties. It is believed that the listening comprehension test is an efficient tool of differentiating between a GVPR and a dyslexic student. The differentiation between GVPR and students with specific disability will be the crucial factor for our further analysis. In Czech background, the diagnosis of dyslexia is dominant. It is possible, that if both diagnosis and intervention put emphasis on decoding skills of a student, he or she can be diagnosed wrongly. Subsequently, the wrong diagnosis can result in wrong intervention practice and influence the students reading development. Another step will be comparison of a dyslexic student and a reader with unspecified reading disability. The study will observe what scores do these two group have similar and where is their profile visibly different. The situation will be very similar in case of students with developmental dysphasia. These students have problems mainly with reading comprehension. Even students with speech impairment (with dysphasia) can reach similar reading profile, in some components. Supposedly, their scores will be low in language awareness tests. Their level of reading comprehension is low and therefore, their syntactic awareness is poor. As mentioned at the beginning, this article is based on the first phase of the data collection (T1). The second phase took place approximately 6 months later. Even in $4^{\text {th }}$ grade, it is possible that 6 months play an important role in student's reading development. It is a question whether the group of GVPR will stay the same after the analysis of the data from the second phase. Silent reading test is another tool that would be beneficial for the diagnostic portfolio, as it is not a part of the Czech standardised test material. Another point of discussion will be the possible influence of personal character traits on the results. Is it possible that the student was stressed because of his character and emotional traits (introversion, neuroticism, uncertainty, shyness, embarrassment, fear of unknown, etc.)? This stress might have had an impact on his/her results. Does the reader achieve higher scores when he or she reads silently on his/her own?

There is no doubt that there are many factors that influence the reading development of a student (intellect, environment, etc.) In early education, the behaviour of parents plays a major role in students' attitude towards reading and influences their reading abilities. The reading development and difficulties are also heavily influenced by the attitude of the teacher -their sensitivity and receptiveness of the problems. Last but not least, the overall reading profile of a student is also impacted by his/her character traits and attitude towards his/her own reading competences. The study will also observe how similar are the attitudes of a student, his/her parents and his/her teacher towards his/her reading profile.

Both quantitative and qualitative analyses of all aspects of literacy are also important for a change in advisory paradigm. We would like to change the approach of primary diagnostics and successive intervention which prevails in the Czech Republic. In our opinion, it is crucial for the students' reading development that they get systematic support as soon as possible. If it is 
possible to identify the precursors of difficulties, high-risk students could be identified very early after starting their school education. An appropriate intervention could be put in place to help develop all their reading competences which would then help to prevent falling behind in reading. An individualized intervention programme could be designed thanks to a larger set of tests used for diagnosis, focusing on broader spectrum of reading competences, as well as on language awareness.

\section{Bibliographic references:}

BISHOP, D. - NORBURY, C. 2002. Inferential processing and story recall in children with communication problems: a comparison of specific language impairment, pragmatic language impairment and high-functioning autism. International Journal of Language \& Communication Disorders, vol. 37, n. 3, pp. 227-251. ISSN 1460-6984.

CARAVOLAS, M. - VOLÍN, J. 2005. Baterie diagnostickych testu gramotnostnich dovednosti pro zaky 2. až 5. rocniku. Prague: IPPP. ISBN 80-86856-06-2.

CATTS, H. W. - HOGAN, T. P. - FEY, M. E. 2003. Subgrouping poor readers on the basis of individual differences in reading-related abilities. Journal of Learning Disabilities, vol. 36, n. 2, pp. 151-164. ISSN 00222194.

CATTS, H. W. - HOGAN, T. P. - ADLOF, S. M. - BARTH, A. E. 2003.

440 The simple view of reading: Changes over time. Society for the Scientific Study of Reading Annual Convention, Boulder, CO.

CONNERS, F. A. - OLSON, R. K. 1990. Reading comprehension in dyslexic and normal readers: A component-skills analysis. In BATOLA, D. A. (Ed) - FLORES D'ARCAIS, G.B. (Ed) - RAYNER, K. (Ed) Comprehension processes in reading. Hillsdale, NJ, England: Lawrence Erlbaum Associates, Inc. pp. 557-579.

ELLIS, N. C. - LARGE, B. 1987. The development of reading: As you seek so shall you find. British Journal of Psychology, vol. 78 n. 1, pp.1-28. ISSN 0022-3980.

FOORMAN, B. R. - FRANCIS, D. J. - FLETCHER, J. M. SCHATSCHNEIDER, C. - MEHTA, P. 1998. The role of instruction in learning to read: Preventing reading failure in at-risk children. Journal of Educational Psychology, vol. 90 n. 1, pp. 37-55. ISSN 0022-0663.

GOUGH, P. B. - TUNMER, W. E. 1986. Decoding, reading, and reading disability. RASE: Remedial \& Special Education, vol. 7, n. 1, pp. 6-10. ISSN 0741-9325.

JUCOVICOVA, D. - ZACKOVA, H. 2008. Reedukace specifických poruch učení u dětí. Praha: Portál. ISBN 978-80-262-0645-3.

KESSLER, B. - CARAVOLAS M. 2011. Weslalex: West Slaviclexicon of child-directed printed words. Available online http://spell.psychology.wustl.edu/weslalex. 
KUCHARSKA, A. 2014. Riziko dyslexie. Pregramotnostni schopnosti a dovednosti a rozvoj gramotnosti v rizikovych skupinach. Prague: PedF 2014. ISBN 9788072907847.

LEACH, J. - SCARBOROUGH, H. S. - RESCORLA, L. 2003. Lateemerging reading disabilities. Journal of Educational Psychology, vol. $95 \mathrm{n}$. 2, pp. 211-224. ISSN 0022-0663.

MATEJCEK, Z. ET AL. 1987. Zkouška čtení. Bratislava: Psychodiagnostika, s.r.o.

MATEJCEK, Z. 1995. Dyslexie: specifické poruchy čtení. Jinočany: H\&H. ISBN 808578727X.

NATION, K. 2005. Children's reading comprehension difficulties. In: SNOWING M. J. - HULME C., editors. The Science of Reading: A Handbook. Oxford: Blackwell, pp. 248-266. ISBN 978-1-4051-1488-2.

NATION K. - CLARKE P. - MARSHALL C. M. - DURAND M. 2004. Hidden language impairments in children: parallels between poor reading comprehension and specific language impairment? Journal of Speech Language and Hearing Research, vol. 47, n. 1, pp. 199-211. ISSN 10924388.

NATION, K. 2011. Children's Reading Comprehension Difficulties: Nature, Causes, and Treatments. In SNOWLING, M. J. - HULME, C. - NATION, K. The Science of Reading: A Handbook. Oxford: Blackwell, pp.248-265. ISBN 978-1-4051-1488-2.

RICKETTS, J. - JONES, C. - HAPPÉ, F. - CHARMAN, T. 2013. Reading Comprehension in Autism Spectrum Disorders: The Role of Oral Language and Social Functioning. Journal Of Autism \& Developmental Disorders, vol. 43, n. 4, pp. 807-816. ISSN 1573-3432. DOI: 10.1007/s10803-012$1619-4$.

RUTTER, M. - YULE, W. 1975. The concept of specific reading retardation. Child Psychology \& Psychiatry \& Allied Disciplines, vol. 16, n. 3, pp. 181-197. ISSN 0021-9630.

SCHOFFELOVA, M. - MIKULAJOVA, M. 2012. Vyvoj ruznych aspektu cteni ve slovenstine. Pedagogika, vol. 61, n. 1-2, pp. 111-125. ISSN 00313815.

SHARE, D. L. 1996. Word Recognition and Spelling Processes in Specific Reading Disabled and Garden-variety Poor Readers. Dyslexia, vol. 2, n. 3, pp. 167-174. ISSN 1099-0909.

SNOWLING, M. J. 2009. Changing concepts of dyslexia: nature, treatment and comorbidity. Journal of Child Psychology and Psychiatry, vol. 53, n. 9, pp. 1-3. [on-line]. [cit. 2014-06-11] Available online: http://www.wiley.com/bw/vi.asp?ref=0021-9630\&site=1. ISSN 1469-7610. SNOWLING, M. J. - HULME CH. 2011. Evidence-based interventions for reading and language difficulties: Creating a virtuous circle. British Journal of Educational Psychology. vol. 81, n. 1, pp. 1-23. ISSN 2044-8279.

STANOVICH, K. E. 1988. Explaining the differences between the dyslexic and the garden-variety poor reader: The phonological-core variabledifference model. Journal of Learning Disabilities, vol. 21, n. 10, pp. 590604. ISSN 0022-2194. 
TORPPA, M. - TOLVANEN, A. - POIKKEUS, A. - EKLUND, K. LERKKANEN, M. - LESKINEN, E. - LYYTINEN, H. 2007. Reading development subtypes and their early characteristics. Annals of Dyslexia, vol. 57, n. 1, pp. 3-52. ISSN 0736-9387.

WILDOVA, R. 2005. Rozvijeni pocatecni ctenarske gramotnosti. Prague: Charles University. ISBN 80-729-0228-8.

ZELINKOVA, O. 2009. Poruchy uceni. Prague: Portal. ISBN 978-80-7367514-1.

PhDr. Pavla Presslerová, Ph.D, Charles University Prague

Faculty of Education

Department of Psychology

Myslíkova 7

11000 Prague

Czech Republic

pavla.presslerova@pedf.cuni.cz 